\title{
Ethics And Executives: A Cross-Cultural Comparison Of Japan, Taiwan, And The United States
}

\author{
Chunlong Huang, (E-mail: chunlong@nsu.nova.edu), Nova Southeastern University \\ Bahaudin G. Mujtaba, (E-mail: mujtaba@sbe.nova.edu), Nova Southeastern University \\ Frank J. Cavico, (E-mail: cavico@nova.edu), Nova Southeastern University \\ Randi L. Sims, (E-mail: sims@nova.edu), Nova Southeastern University
}

\begin{abstract}
Globalization has facilitated the interaction of people from diverse cultures. As more firms now operate internationally, ethical issues tend to increase, and thus managers nowadays face more complicated situations that challenge their ability to reason morally. In the previous studies, cultural difference is often used to explain the ethical conflicts between home and host country. This research investigates the moral reasoning abilities of top-level business managers of three cultural groupsthe U.S. and Japanese expatriate managers in Taiwan, and local Taiwanese managers. Kohlberg's (1969, 1976, 1984b) theory of cognitive moral development (CMD) and Rest's Defining Issues Test Version Two (DIT-2) were used to access the level of ethical reasoning of these business practitioners. Hofstede's (2001) theory of cultural dimensions was used to describe differences among these managers. A DIT-2 survey packet was sent to 750 managerial and executive level employees at a variety of organizations in Taiwan. Results indicate that personal characteristics (gender, age, education level) and organizational factors (ethics code, ethical training) may not significantly affect one's ethical perception. Conversely, cultural difference may be diminished and possible ethical convergence may appear through acculturation to local business environment.
\end{abstract}

\section{INTRODUCTION: CULTURE, VALUES, BELIEFS, AND ATTITUDES}

M

anagers often face situations that challenge their ability to reason morally (Weber \& Wasieleski, 2001). An earlier study conducted by Carroll (1975) found between 65 percent and 84 percent of all managers face ethical dilemmas at least once in their career. Other researchers have confirmed that managers at all levels often feel under pressure to compromise their personal principles for their organizations (Badaracco \& Webb, 1995; Harris, 1990; Lincoln, Pressley, \& Little, 1982; Posner \& Schmidt, 1984, 1987). With the rapid integration of the world economy, many business organizations now operate in a "borderless world" (Robbins, 1994), and ethical issues tend to increase possibly due to cultural differences. As a result, global managers often must navigate the perplexing "gray zone" that arises when two cultures and two sets of ethics meet (Donalson \& Dunfee, 1999). The purpose of this research is to investigate empirically whether there are differences among expatriate and local managers in Taiwan.

The concept of culture may generally be defined as the shared beliefs and symbols of a group of individuals (McDonald, 2000). Geertz (1973) defined culture as "the fabric of meaning in terms of which human beings interpret their experiences and guide their actions" (p. 145). Swidler (2001) contends that individuals normally rely on cultural values as guides to action to the extent that values provide rationales for predetermined ends.

Values are acquired through lifestyle altering experiences, such as childhood and education (Hofstede, 1991; Karahanna, Evaristo, \& Srite, 2005; Velasquez, 1998). It is believed that individuals learn the knowledge, attitudes, and behavior from their ancestors. Such social learning provides general norms and values, and thus forms the basis of culture (Rogers, 1988). According to Schwartz and Bilsky (1987), values are concepts or beliefs about desirable end states or behaviors that (a) transcend specific situations, (b) guide selection or evaluation of behavior or events, and (c) 
are ordered by relative importance. Keeling (1981) exemplified values as an individual's "theory of what his fellows know, believe and mean, his theory of the code being followed, the game being played, in the society into which he was born" (p. 58). The widely accepted shared customs or norms in society provide a mechanism that Hofstede (1997) called as "software of the mind" or "mental programs," which shapes the values that individuals acquire in society and hold onto steadfastly. Though values may change in response to major changes in technology, economy, and politics, they are fairly stable (Schwartz, 1992).

According to Rokeach (1973), a value is an enduring belief that a specific mode of conduct is personally or socially preferable to an opposite mode of conduct. A value system is an enduring organization of beliefs concerning preferable modes of conduct or an end-state of existence along a continuum of relative importance (Rokeach, 1973). The value system has a strong effect on what is perceived as right or wrong, acceptable or unacceptable, and ethical or unethical (Lu, Rose, \& Blodgett, 1999). Thus, a person raised in a particular culture may acquire and cultivate certain attitudes, without even questioning the validity of these attitudes (Christie, Kwon, Stoeberl, \& Baumhart, 2003), though individuals may differ in their value system and in the relative stability of these beliefs (Karahanna et al., 2005).

National culture is "a collective programming of the mind which distinguishes one group from another" (Hofstede, 1991, p. 260). Hofstede (1984) argued that "despite the regional differences within a particular nation, we can still distinguish some ways of thinking that most inhabitants share and that we can consider part of their national culture or national character" (p. 77). Because the steady and long-lasting characteristic of culture, therefore, "national cultures are extremely stable over time" (Hofstede, 2001, p. 34).

Culture has been recognized as one of the most influential variables influencing one's ethical decision making (Singhapakdi, Vitell, \& Leelakulthanit, 1994). A person raised in a particular culture may acquire and cultivate certain attitudes, without even questioning the validity of these attitudes (Christie et al., 2003). Culture seems to be closely connected with one's perception about right or wrong, acceptable or unacceptable, and ethical or unethical (Lu et al., 1999). Many cross-cultural studies have shown that national culture has an influence on one's ethical attitude and behavior (Allmon, Chen, Pritchett, \& Forrest, 1997; Grunbaum, 1997; Honeycutt, Siguaw, \& Hunt, 1995; Hood \& Logsdon, 2002; Jackson, 2001; Okleshen \& Hoyt, 1996; Singhapakdi, Rallapalli, Rao, \& Vitell, 1995).

\section{Cultural and Business between East and West}

East and West cultures differ tremendously in many ways, reflecting in attitudes, values, and norms of the society where they have been developed or will be limited in their applicability elsewhere (Michailove, 2000). One significant difference between Eastern and Western culture in the workplace is individualism and collectivism (Hofstede, 2001). Individualists (West) tend to decide and act on the basis of whether an action leads to personal gain whereas collectivists (East) are apt to consider their actions from the group viewpoint. In addition, individualists value independence and self-sufficiency. Conversely, collectivists value social relationships and sharing of material as a means of maintaining a social network of reciprocation (Hutchings \& Murray, 2003).

Another significant difference between Eastern and Western culture, according to Hofstede and Bond (1988), is Confucian Dynamism. Hofstede and Bond identified the Confucian dynamism dimension following a survey of Chinese students. This dimension measures the extent to which a culture emphasizes values, which are oriented towards the future (long-term orientation) in contrast to those, which are oriented towards the past and the present (short-term orientation). The long-term orientation contains values indicating a dynamic, future-oriented mentality such as hard work ethic, persistence, respect for status, thrift, concept of time, and having a sense of shame. Countries such as Japan, Hong Kong, Taiwan, and South Korea that have high Confucian Dynamism scores tend to associate more with these values. On the other hand, the short-term orientation contains values representing a static mentality focused on the past and present, such as reciprocation, face, and tradition. Examples of nations with low on the Confucian Dynamism include West Africa, Canada, and Pakistan (Hofstede \& Bond, 1988).

The issue of saving face is an example to distinguish the East culture from the West. According to Hofstede and Bond (1988), people in nations with high Confucian Dynamism scores such as Japan, Hong Kong, Taiwan, and 
Thailand tend to emphasize personal steadiness and stability, saving face, respect for tradition, and reciprocation of greetings, favors, and gifts. Among these cultural characteristics, face issue is extremely important to most Asian people. To those people, business or non-business, losing face is equivalent to shame, and protecting one's face is to avoid embarrassment and conflicts. On the contrary, in Western cultures, shame may be the least socially acceptable emotion, as it is believed to be a mark of incompetent social members (Goffman, 1967). Researchers also found that shame is more "deeply felt" in Japan than in America (Benedict, 1989, p. 224; Edelmann, 1990), and Chinese are more concerned and aware of the meaning of shame than Americans and Italians (Rosch, 1978; Shaver, Wu, \& Schwartz, 1992). Both Japanese and Taiwanese business people tend to attach great importance to maintaining group harmony, that is, to save everyone' face.

Ford and Honeycutt (1992) compare the business practices between the U.S. and Japan using national culture as a basis. They found that Japanese are underlining on process (appearance) rather than the result (bottom line), more concerned for the protection and perseverance of the society as a whole (collectivism), more hierarchical in societal structure, and devoted to long-term survival that may seem predatory to other nations. In the cross-cultural studies, Vaill (1996) stated that "a cultural key is an understanding of the meaning of a given situation from the point of view of those cultural representatives who are involved in it in any way, both those of the culture in which the situation is occurring and those of other cultures" (p. 157). Schneider (1989) also suggested that variation in the strategic orientation of executives is attributable to differences in national culture value. Empirical studies of cross-cultural comparisons have shown differences in the value systems and ethical beliefs of people from different cultures (Blodgett, Lu, Rose, \& Vitell, 2001; Cherry, Lee, \& Chien, 2003; Hay, Larres, Oyelere, \& Fisher, 2001; Hofstede, 2001; Moon \& Franke, 2000; Pitta, Fung, \& Isberg, 1999).

Western and Eastern ethics theories share similarities and differences in points of view (Venezia, 2004). One example is gift-giving. For example, in Chinese and Japanese business practice it is customary to present a small, carefully chosen business gift, which conveys a great deal of respect and is a sign that the business relationship is valued by the giver. In Brand and Slater's (2003) study, most Australian managers also agree that gift-giving is simply the building of trust and strong relationships, not involving corrupt practice. Yet it is generally agreed that gifts whose purpose is to influence a decision-maker's judgment is actually or essentially a bribe (Pitta et al., 1999).

Opinions are also widely divided about pursuing the ethical relativism between the East and West. A cross-cultural study of Machiavellianism was conducted by Christie and Geis (1970) using Mach IV Scale administrated to Chinese and to European Americans. Their results indicate that Chinese participants had much higher Machiavellian scores (tend to manipulate strategies of social behavior). Yet several researchers suggested that the Chinese are highly relativist in their approach to decision making, that is, that there are no moral absolutes and ethical behavior depends on the situation (Hampden-Turner \& Trompenaars, 1993; Jackson et al., 2000; Ralston, Yu, Wang, Terpstra, \& He, 1996). Another study conducted by Whitcomb et al. (1998) found that U.S. students, when making moral decisions, displayed more idealistic concerns, such as a concern for the welfare of others, for the environment, and avoiding harm to others, than Chinese students.

\section{Moral Reasoning and Culture}

According to Rest's (1994a) model of moral action, individuals' ethical reasoning process begins with ethical sensitivity (identification of an ethical dilemma). Once an ethical dilemma has been identified, an individual enters a process of prescriptive reasoning in which they formulate possible moral actions in a given situation (moral reasoning). An individual then decides which action to pursue (morally-driven or other value-driven). In the final stage, an individual implements the decision and acts (ethical character). Rest, along with Jaccard and Wan (1986), asserted that this ethical reasoning process is universal across cultures. However, empirical studies of cross-cultural comparisons have shown differences in the value systems and ethical beliefs of people from different cultures (Blodgett et al., 2001; Cherry et al., 2003; Hay et al., 2001; Hofstede, 2001; Moon \& Franke, 2000; Pitta et al., 1999), and cultural difference highlights differences in what might be considered ethically acceptable and unacceptable behaviors (Tsui \& Windsor, 2001; Weaver, 2001).

MacDonald (2000) argues that the circumstance that activate and affect the ethical reasoning process may differ across cultures (p. 92). He states that "different cultural and linguistic backgrounds lead to different ways of 
perceiving the world" (p. 94), and these cultural differences affect individuals' ethical reasoning. Cohen et al., (1992) stated that individuals from diverse cultures differ in their sensitivity to ethical situations. Previous studies have used the structural elements of culture defined by Hofstede $(1980,1991)$ and Hampden-Turner and Trompenaars (1993) to depict that culture may influence individuals' moral reasoning (Desai \& Rittenburg, 1997; Vitell, Nwachukwu, \& Barnes, 1993).

According to Hampden-Turner and Trompenaars (1993), managers from diverse cultural backgrounds may have different perceptions of organizational goals. He found that American managers had a stronger tendency to view the company as primarily a profit-making entity. Japanese and Taiwanese managers, by contrast, were more likely to view the company as attaining the well being of various stakeholders such as employees and customers rather than simply making profits. Thorne and Sauders (2002) argue that "A relative orientation towards considering a situation in relation to other domains implies that individuals may identify ethical dilemmas in a broader range of situations than counterparts with an orientation towards regarding issues and events as singular and self-contained" (p. 6).

\section{Ethical Reasoning and Managers}

The moral reasoning ability of managers is essential because it is associated with risk assessment and fraud detection (Bernardi, 1994). Lewin and Stephens (1994) found that postconventional individuals are particularly likely to become leaders, and as such they have a special opportunity for organizational impact. Albrecht (1988) found that an executive who applies a high level of moral reasoning in evaluating personal moral dilemmas is likely to use similar cognitive processes to deal with dilemmas facing the organization. Jurkiewicz and Massey (1998) found that effective executives use more postconventional thinking (with mean $P$ score of 65.14) than ineffective executives (with mean $P$ score of 33.57).

Kracher, Chatterjee and Lundquist (2002) used DIT to compare ethical reasoning abilities of business students in India and U.S., no significant differences were found between them. Other studies use DIT to determine professionals' moral reasoning level and development mainly focus on accounting field, and the research findings are mixed. For example, Armstrong (1987) employed the Defining Issues Test (DIT) to explore accountants' ethical reasoning and moral development. Tsui and Windsor (2001) compared Australian and Hong Kong Chinese auditors. Ho (1997) examined Taiwanese accounting students by using six-story DIT. Venezia (2004) used DIT to compare U.S. and Taiwanese accounting students in terms of their ethical reasoning. She found that the Taiwanese accounting students score slightly higher (with mean $P$ scores of 31.6) than U.S. accounting students (with mean $P$ scores of 27.81). This study sets out to further investigate this variable by testing the following hypotheses:

H1: There are no significant differences in the ethical reasoning ability between U.S. expatriate managers, Japanese expatriate managers and local managers in Taiwan.

Moral reasoning level of an individual has a direct effect on moral or ethical behavior (Rest et al., 1986). Trevino (1986) suggested that moral reasoning level is central to the process of decision making and is influenced by both situational variables and individuals. Many researchers have examined various individual or contextual influences on moral reasoning as the dependent variable to better understand individual differences in moral reasoning (Wimbush, 1999). It has been found by researchers that gender, age, education, and taking ethics courses may affect one's moral reasoning ability (Elm, Kennedy, \& Lawton, 2001; Jones \& Hiltebeitel, 1995).

\section{Gender}

While differences in gender has been extensively studied and been empirically tested as a demographic independent variable in ethics research (Ford \& Richardson, 1994), varied results have been found. Some researchers indicate that ethical perceptions are similar between male and female (Ergeneli \& Arikan, 2002; Kidwell, Stevens, \& Bethke, 1987; McCuddy \& Peery, 1996; McNichols \& Zimmerer, 1985; Smith \& Rogers, 2000; Stevens \& Stevens, 1987; Tsalikis \& Oritz-Buonafina, 1990), or that gender does not have any impact on one's ethical attitudes (McCuddy \& Peery, 1996; Serwinek, 1992; Smith \& Rogers, 2000, 2001). Daniel, D'Andrea, and Heck (1995) conducted a study of Hawaiian youths and investigated possible difference in the moral development of male and 
female individuals. They concluded that gender differences in moral reasoning did not exist between male and female. Derry used Gilligan's and Kohlberg's models to study managers' moral reasoning and found no significant differences in moral reasoning between male and female managers (Trevino, 1992). But she (1989) explained that the result may be due to the fact that "women's roles in industry still beg definition" (p. 861). This study sets out to further investigate this variable by testing the following hypotheses:

H2: There are no significant differences in the ethical reasoning ability between male and female managers.

Others found females are more concerned about ethical issues (Beltramini, 1984; White, 1999), are more apt to against to unethical actions (Miesing \& Preble, 1985; Ruegger \& King, 1992; Weeks, Moore, McKinney, \& Longenecker, 1999), and thus act more ethically (Arlow, 1991; Sweeney, 1995; Wahn, 2003; Whipple \& Swords, 1992) or demonstrated higher levels of moral reasoning ability than males in general (Cohen, Pant, \& Sharp, 1998; Elm et al., 2001). In a meta-analysis of prior ethical decision-making research, Borkowski and Ugras (1998) concluded that women more often recognize critical ethical issues in business situations and/or more often selected the ethically preferable action. Trevino (1992) found that women did score slightly higher in the DIT test than men, though James Rest (1986) reported that differences between men and women when responding to dilemmas in the DIT are minimal.

Age

In their study, McCabe et al (1991) concluded that "age correlated positively with ethical decision making; suggesting that maturity enhances ethical decision making" (p. 958). It is generally agreed that older individuals tend to be more ethical or possess a more strict view of moral issues than younger ones. As individuals progress through the experience of life, Kohlberg (1984a) contends, they should develop higher stages of moral cognition. A survey conducted by Ruegger and King (1992) suggested that students in the 40 plus years age group were the most ethical. The findings are consistent with Allmon et al (2000) research that older students exhibit more ethical inclinations (Allmon et al., 2000; Borkowski \& Ugras, 1998). Accordingly, younger people tend to be less ethical than older people (Mellahi \& Guermat, 2004; Miesing \& Preble, 1985), or more tolerant over a wide range of issues (Longenecker, McKinney, \& Moore, 1988), as older workers had stricter interpretations of ethical standards (Serwinek, 1992). This study sets out to further investigate this variable by testing the following hypotheses:

H3: There is no relationship between age and level of ethical reasoning for managers.

Conversely, Eynon et al (1997) found that age has no effect on the level of moral reasoning. In a survey to 400 managerial and executive level employees of Fortune 500 firms, Forte (2004b) did not find a relationship between age and ethical reasoning. Elm and Nichols (1993) found that younger managers exhibited higher moral reasoning stages than older managers which is contrary to Kohlberg's assertion. Glover et al. (1997) even concluded that age was not a determining factor at all in terms of ethical decision making.

\section{Education}

Piaget concluded from his work that schools should emphasize cooperative decision-making and problem solving, nurturing moral development by requiring students to work out common rules based on fairness. It was believed that formal education enhances students' critical thinking, and critical thinking encourages the consideration of little stories of individuals and big stories of business (Kienzler, 2001). One of the most prominent ethical characteristics of critical thinking is the identification and questioning of assumptions built into situations, information, arguments, and style (Brookfield, 1991).

Rest (1986) states that years of formal education indicated a far greater predictor of ethical reasoning in moral development. He found that a person's DIT score increases between senior high school and college graduation, and after formal education ends, "adults in general do not show much advancement beyond that accounted for by their level of education" (Rest, 1979, p. 113). Rest and Narvaez (1994a) also found that many studies "reveal that increased education is generally associated with higher levels of moral judgment" (p. 28). Other studies also confirmed that 
education is positively related to the moral reasoning ability (Bay \& Greenberg, 2001; Elm et al., 2001; Smith, Skalnik, \& Shalnic, 1999; Trevino, 1992; Wimalasiri, 2004; Wimalasiri, Pavri, \& Jalil, 1996).

In his longitudinal research, Trevino (1992) found significant positive correlations between adult moral development and educational level ranging from 0.54 to 0.69. Trevino's result supports Rest's (1979) finding that there is a strong correlation between education and the DIT scores. Dubinsky and Ingram (1984) found that higher levels of education made salespeople more cognizable of moral and ethical issues and what is considered to be acceptable or unacceptable business behavior than those with lower levels of education. In a study of examining the ethical orientations of business managers and business students in Singapore, Wimalasiri et al., (1996) also found that the moral judgment scores are influenced by the subjects' levels of education. However, both Serwinek (1992) and Forte (2004a) found no statistically significant relationship between an individual's education and his/her moral reasoning ability. This study sets out to further investigate this variable by testing the following hypotheses:

H4: There are no significant differences in the ethical reasoning ability based on managers' education level.

\section{Ethics Education}

Some researchers believe that offering an ethics education to business students would have positive effects on their ethical behaviors (Borkowski \& Ugras, 1998; Garaventa, 1998; Klenin, 1998). In fact, many Western business schools have made business ethics course as a compulsory part of their curricula (Lam, 2004). However, different voices have been raised to the necessity and effectiveness of ethics education. Opponents such as Levin's (1989) article titled Ethics Courses: Useless in 1989 in the New York Times. He argued that "telling right from wrong is not that hard, the hard part is overcoming laziness and cowardice to do what one perfectly well knows one should" (p.21). Bunke (1988) criticized that "most ethical questions can be answered by reading the works of Plato and other writers, a class in business ethics could only remind students that the business system will endure only so long as it is solidly rooted in meaningful idealism" (p. 5). Henderson (1988) stated that "ingrained character trait which must be implanted within the first five years of life, the spiritualized intention to do good cannot be acquired through education at any later point in life" (p. 52).

However, Purcess (1977) surveyed a group of successful business men who were Dartmouth MBA students ten years ago. Most of the students reported that they have been helped toward ethical behavior in business by their study of managerial ethics during their student days. Bishop (1992) argued that "a person's value set is not a static or permanent collection. Instead it seems more likely that a person's value system may be subject to great modification and refinement over time" (p. 294).

Snodgrass (1993) investigated whether there were significant differences in the principled moral reasoning between undergraduate business majors and non-business majors. He studied 669 undergraduate students enrolled in day classes in arts and humanities, social science, natural science, and business at two private colleges, and used the short form of Rest's Defining Issues Test (DIT) to assess the principled moral reasoning of the students. He also investigated whether there were significant differences between lower and upper division students. The results indicate that the mean $P$ score of upper division business majors was 2.6 points below the mean of upper division nonbusiness majors which recommend that there should be additional and continued emphasis on ethics education for business students.

Mayhew (2004) investigated whether curricular-based learning influences the development of students' moral reasoning abilities. He surveyed 771 students enrolled in the courses by using the DIT-2 and found that upward changes in moral reasoning over the term were affected by course enrollment and pedagogy. In situations where students were enrolled in courses with explicit moral emphases, the introduction course and the service-learning course demonstrated developmental gains. Larsen (2004) also used DIT-2 to examine whether adevelopment program can have a positive effect on moral reasoning development, academic achievement, and behavior of college students. The results supported the notion that college students can develop morally. Wu (2003) investigated the impact of ethics education on business students in two universities located in Taiwan and China. He found that after taking 
ethics courses, students from both universities demonstrated significant improvements in the ethical weighting of their individual values, their recognition of ethical issues and their performance as ethical decision-makers.

Conversely, other studies showed different results of taking ethics education or training on moral reasoning or development. Abdolmohammadi and Sultan (2002) used DIT to examine the ethical reasoning and behavior of accounting and finance students. They found no significant difference whether they had taken an ethics course or not. For the business professionals, Shank (2005) used DIT-2 to investigate the mental processes of pharmaceutical sales representatives. He found that participation in formal ethics training did show a significant relationship with cognitive moral development among these salespeople. His finding indicates that ethical training increases the likelihood of having a high level of moral reasoning. However, the sample group in the study covers only 63 employees in one company in the same industry. Evans (2005) used DIT to survey African-American business professional and found that there is no difference between ethical maturity level and formal ethics training. This study sets out to further investigate this variable by testing the following hypotheses:

H5: There are no significant differences in the ethical reasoning level between managers based on whether they have taken a business ethics or ethics course.

\section{METHODOLOGY}

The DIT-2 survey packet used in this study includes the following: (a) Cover letter, (b) DIT-2 questionnaire, (c) DIT-2 answer sheet, and (d) a supplemental demographic information sheet. The supplemental questionnaire included items which measured executive perceptions and considerations both in the workplace as well as in their personal life while making an ethical decision. The completed DIT-2 forms were sent to the Center for the Study of Ethical Development at University of Minnesota for scoring. The yielded N2 scores from DIT-2 survey will reflect ethical reasoning stages of these ethnic groups. Managers with higher N2 scores are more likely to use higher staged reasoning than managers with lower $\mathrm{N} 2$ scores. ANOVA, $t$-test and correlation were used to test the hypotheses in the means of all researched variables on inter-group basis.

The U.S. expatriate managers were given the original form of DIT-2. Due to some Japanese and Taiwanese senior managers may not be proficient in English, the author translated the DIT-2 into Japanese and Chinese Mandarin with minor changes. For example, the author modified the names of the roles in the DIT-2 stories with understandable names both the Japanese and Taiwanese participants are familiar with. Overall, the stories and questions in the DIT-2 were deliberately translated without altering its contents and meanings.

Since the DIT-2 was the only instrument used uniformly across three cultures, it is imperative to be cautious during translation to avoid cultural bias. Hofstede (1980) noted that in cross-cultural research, it is essential that versions of a scenario presented to subjects in each country be linguistically equivalent. Hofstede suggests that researchers can use de-centering, a process in which researchers from different cultures are involved in developing research questions, to avoid cultural bias (Hofstede, 1997). Hence, the survey questionnaire in the research was translated into Japanese and Chinese by the author and back-translated into English by two research associates (Brislin, 1980). It was found that the original and back-translated English versions were virtually identical in meaning.

The sample population of this study consists of U.S. and Japanese expatriate managers in Taiwan as well as local Taiwanese managers who work for Taiwan-based multinational corporations. For U.S. and Japanese expatriate managers, the DIT-2 questionnaires were mailed to the: (a) currently registered members of the American Chamber of Commerce in Taipei, (b) currently registered members of the Japanese Chamber of Commerce and Industry in Taipei, and (c) lists according to the Japanese Taiwan Research Center. Questionnaires were mailed to potential subjects according to the lists of Foreign Enterprises in Taiwan (Chang, 2004), and lists of The Manager Directory in Taiwan (Chao, 2002). The respondents comprised of 750 executives and managers in more than 400 companies, ranging over manufacturing, service, and high-tech industries. Of the 137 returned surveys, a total of 15 surveys were purged from the analysis due to incomplete answers. While the remaining 122 completed surveys were returned over a four-week period, representing a response rate of $16.3 \%$. The 122 surveys consist of 38 from the U.S. group, 39 from Japanese group, and 45 from Taiwanese group. 


\section{RESULTS OF FINDINGS}

The N2-scores was received from The Center for the Study of Ethical Development at University of Minnesota based on 122 survey questionnaires. A One-Way ANOVA was used to determine whether there were significant differences in ethical reasoning ability based on nationality. The results indicated that there were no significant differences $(F=1.417 ; p=0.247)$ in the ethical reasoning ability between U.S. expatriate managers, Japanese expatriate managers and local managers in Taiwan. Therefore, null hypothesis 1, "There are no significant differences in the ethical reasoning ability between U.S. expatriate managers, Japanese expatriate managers and local managers in Taiwan," is accepted.

A t-Test was used to determine whether there were significant differences in ethical reasoning ability for managers based on gender. The probability of 0.214 (Levene's test has a significance $0.029<0.05$, equal variances not assumed) was greater than the cut-off of 0.05 , thus the null hypothesis 2 , "There are no significant differences in the ethical reasoning ability between male and female managers," is accepted.

The correlation coefficient between managers' age and $N 2$-score was 0.105 . Given the sample size of 122 , the probability for this correlation is 0.249 . Therefore, null hypothesis 3 , "There is no relationship between age and level of ethical reasoning for managers," is accepted.

In this study, most of these executives and managers (55.7\%) reported that they had college degrees, $34.4 \%$ of them possessed professional or higher degrees. A One-Way ANOVA was used to determine whether there were significant differences in the ethical reasoning ability based on managers' education level. The results indicate that there were no significant differences $(F=0.899 ; p=0.410)$ between managers' education level and ethical reasoning ability. Therefore, null hypothesis 4 , "There are no significant differences in the ethical reasoning ability based on managers' education level," is accepted.

A t-Test was used to determine whether there were significant differences in the level of ethical reasoning between managers based on whether they have taken a business ethics or ethics course. The results showed that the probability of 0.677 (Levene's test has a significance $0.604>0.05$, equal variances assumed) was greater than the cutoff of 0.05 , thus the null hypothesis 5, "There is no significant difference in the ethical reasoning level between managers based on whether they have taken a business ethics or ethics course," is accepted.

\section{LIMITATIONS OF THE STUDY}

Certain limitations of this study must be acknowledged.

First, the author relied solely on perceptual measures - the Defining Issues Test Version Two (DIT-2)—as the only survey instrument. The ethical decision-making process of managers to prearranged ethical dilemmas may be different from real-life cases. Future research efforts might concentrate on qualitative ways to investigate how expatriate managers perceive and interpret local environment influencing their ethical decisions.

Second, the author relied solely on top-level executives for the sample. Although this focus enabled us to closely make the content of our questions suitable to the sample, it does limit overall generalizability of the study.

Third, the study focused on U.S. and Japanese expatriate managers in Taiwan, the results may not be representative of those found internationally. Future research efforts might use wide-range sample in larger emerging markets such as China and India.

Fourth, although the low response rate is normal, it does limit the overall representability of the sample population. In order to increase the response rate, the authors suggest that future research might use telephone survey instead of using mailed-in survey.

Finally, the study was conducted during Chinese New Year. A considerable number of people pursue new job opportunities after long weekend, making the subjects' list obsolete. In addition, it is also the busiest season in a 
year with routine work piling up, and thus most people are reluctant to take a look at the mailed-in survey. Future researchers should take this into account.

\section{SUMMARY}

This study investigated the differences of ethical reasoning abilities of managers from three ethnic groups. The demographic factors, such as gender, age, education level, and ethics course were taken into account. Although a number of previous studies found that these demographic factors positively correlate with an individual's ethical reasoning ability. The findings in the present study were not supportive. It may be possibly explained that an individual's ethical perception and attitudes may change over a certain time period, and cultural difference may be diminished and possible ethical convergence may appear through acculturation to local business environment.

\section{REFERENCES}

1. Abdolmohammadi, M. \& Sultan, J. (2002). Ethical reasoning and the use of insider information in stock trading. Journal of Business Ethics, 37(2: Part I), 165-173.

2. Albrecht, E. F. (1988). The relationship between protagonist gender in hypothetical moral dilemmas and the use of justice versus care moral orientations. Dissertation: Adelphi University.

3. Allmon, D., Chen, H., Pritchett, T., \& Forrest, P. (1997). A multicultural examination of business ethics perceptions. Journal of Business Ethics, 16(2), 183-188.

4. Allmon, D., Page, D., \& Roberts, R. (2000). Determinants of perceptions of cheating: Ethical orientation, personality and demographics. Journal of Business Ethics, 23(4), 411-422.

5. Arlow, P. (1991). Personal characteristics in college students' evaluations of business ethics and corporate social responsibility. Journal of Business Ethics, 10(1), 63-69.

6. Armstrong, M. B. (1987). Moral development and accounting education. Journal of Accounting Education, 5(1), 27-43.

7. Badaracco, J., J. \& Webb, A. (1995). Business ethics: A view from the trenches. California Management Review, 37(2), 8-28.

8. Bay, D. D. \& Greenberg, R. R. (2001). The relationship of the dit and behavior: A replication. Issues in Accounting Education, 16(3), 367-380.

9. Beltramini, R. (1984). Concerns of college students regarding business ethics. Journal of Business Ethics, 3(3), 195-200.

10. $\quad$ Benedict, R. (1989). The chrysanthemum and the sword: Patterns of Japanese culture. Boston, Mass.: Houghton Mifflin.

11. Bernardi, R. A. (1994). Fraud detection: The effect of client integrity and competence and auditor cognitive style. Auditing, 13, 68-84.

12. Bishop, T. R. (1992). Integrating business ethics into an undergraduate curriculum. Journal of Business Ethics, 11(4), 291-299.

13. Blodgett, J. G., Lu, L. C., Rose, G. M., \& Vitell, S. J. (2001). Ethical sensitivity to stakeholder interests: A cross-cultural comparison. Academy of Marketing Science Journal, 29(2), 190-202.

14. Borkowski, S. \& Ugras, K. (1998). Business students and ethics: A meta-analysis. Journal of Business Ethics, 17(11), 1117-1127.

15. Brand, V. \& Slater, A. (2003). Using a qualitative approach to gain insights into the business ethics experiences of australian managers in china. Journal of Business Ethics, 45(3), 167-182.

16. Brislin, R. W. (Ed.). (1980). Translation and content analysis of oral and written materials. Boston, MA: Allyn and Bacon.

17. Brookfield, S. (1991). On ideology, pillage, language and risk: Critical thinking and the tensions of critical practice. Studies in Continuing Education, 13(1), 1-14.

18. Bunke, H. C. (1988). Should we teach business ethics? Business Horizons, 31(4), 2-8.

19. Carroll, A. (1975). A survey of managerial ethics: Is business morality Watergate morality? Business and Society Review, 13, 58-63.

20. Chang, L. (2004). Foreign enterprises in Taiwan. Taipei, Taiwan: Dun \& Bradstreet International. (Taiwan Branch). 
21. Chao, W. H. (2002). The manager directory in Taiwan. Taipei, Taiwan: China Credit Information Service.

22. Cherry, J., Lee, M., \& Chien, C. (2003). A cross-cultural application of a theoretical model of business ethics: Bridging the gap between theory and data. Journal of Business Ethics, 44(4), 359-371.

23. Christie, P. M. J., Kwon, I. W., Stoeberl, P., \& Baumhart, R. (2003). A cross-cultural comparison of ethical attitudes of business managers: India, Korea and the United States. Journal of Business Ethics, 46(3), 263287.

24. Christie, R. \& Geis, A. (1970). Studies in Machiavellianism. San Diego, CA: Academic Press.

25. Cohen, J. R., Pant, L. W., \& Sharp, D. J. (1992). Cultural and socioeconomic constraints on international codes of ethics: Lessons from accounting. Journal of Business Ethics, 11(9), 687-700.

26. Cohen, J. R., Pant, L. W., \& Sharp, D. J. (1998). The effect of gender and academic discipline diversity on the ethical evaluations, ethical intentions and ethical orientation of potential public accounting recruits. Accounting Horizons, 12(3), 250-270.

27. Daniels, J., D'Andrea, M., \& Heck, R. (1995). Moral development and Hawaiian youths: Does gender make a difference? Journal of Counseling \& Development, 74, 90-93.

28. Derry, R. (1989). An empirical study of moral reasoning among managers. Journal of Business Ethics, 8(11), 855-862.

29. Desai, A. \& Rittenburg, T. (1997). Global ethics: An integrative framework for mnes. Journal of Business Ethics, 16(8), 791-800.

30. Donalson, T. \& Dunfee, T. (1999). When ethics travel: The promise and peril of global business ethics. California Management Review, 41(4), 45-63.

31. Dubinsky, A. J. \& Ingram, T. N. (1984). Correlates of salespeople's ethical conflict: An exploratory investigation. Journal of Business Ethics, 3(4), 343-353.

32. Edelmann, R. J. (Ed.). (1990). Embarrassment and blushing: A component-process model, some initial descriptive and cross-cultural data. Cambridge [England]; New York: Cambridge University Press.

33. Elm, D., Kennedy, E., \& Lawton, L. (2001). Determinants of moral reasoning: Sex role orientation, gender, and academic factors. Business and Society, 40(3), 241-265.

34. Elm, D. \& Nichols, M. (1993). An investigation of the moral reasoning of managers. Journal of Business Ethics, 12(11), 817-838.

35. Ergeneli, A. \& Arikan, S. (2002). Gender differences in ethical perceptions of salespeople: An empirical examination in turkey. Journal of Business Ethics, 40(3), 247-260.

36. Evans, P. K. S. (2005). A study of cognitive moral development theory and moral maturity of AfricanAmerican business professionals. Dissertation: Nova Southeastern University.

37. Eynon, G., Hill, N. T., \& Stevens, K. T. (1997). Factors that influence the moral reasoning abilities of accountants: Implications for universities and the profession. Journal of Business Ethics, 16(12/13), 12971309.

38. Ford, J. \& Honeycutt, E. (1992). Japanese national culture as a basis for understanding Japanese business practice. Business Horizons, 35(6), 27-34.

39. Ford, R. \& Richardson, W. (1994). Ethical decision making: A review of the empirical literature. Journal of Business Ethics, 13(3), 205-221.

40. Forte, A. (2004a). Business ethics: A study of the moral reasoning of selected business managers and the influence of organizational ethical climate. Journal of Business Ethics, 51(2), 167-173.

41. Forte, A. (2004b). Antecedents of managers' moral reasoning. Journal of Business Ethics, 51(4), 313-347.

42. Garaventa, E. (1998). Drama: A tool for teaching business ethics. Business Ethics Quarterly, 8(3), 535-545.

43. Geertz, C. (1973). The interpretation of cultures: Selected essays. New York: Basic Books.

44. Glover, S. H., Bumpus, M. A., Logan, J. E., \& Ciesla, J. R. (1997). Re-examining the influence of individual values on ethical decision making. Journal of Business Ethics, 16(12/13), 1319-1329.

45. Goffman, E. (1967). Interaction ritual: Essays on face-to-face behavior. Garden City, NJ: Anchor Books.

46. Grunbaum, L. (1997). Attitudes of future managers towards business ethics: A comparison of finish and American business students. Journal of Business Ethics, 16(4), 451-463.

47. Hampden-Turner, C. \& Trompenaars, F. (1993). The seven cultures of capitalism: Value systems for creating wealth in the United States, Japan, Germany, France, Britain, Sweden, and the Netherlands (1st ed.). New York: Currency/Doubleday. 
48. Harris, J. (1990). Ethical values of individuals at different levels in the organization hierarchy of a single firm. Journal of Business Ethics, 9(9), 741-750.

49. Hay, D., Larres, P. M., Oyelere, P., \& Fisher, A. (2001). The ethical perception of undergraduate students in computer-related situations: An analysis of the effects of culture, gender and prior education. Teaching Business Ethics, 5(3), 331-356.

50. Henderson, V. E. (1988). Can business ethics be taught? Management Review, 77(8), 52-53.

51. Ho, S. K. (1997). Ethical development of accounting students and public accounting practitioners in Taiwan. Research in Accounting Ethics, 3, 293-303.

52. Hofstede, G. (1980). Culture's consequences: International differences in work-related values. Thousand Oaks, CA: Sage.

53. Hofstede, G. (1984). Culture's consequences: International differences in work-related values (Abridged ed.). Thousand Oaks, CA: Sage Publications, Inc.

54. Hofstede, G. (1991). Cultures and organizations: Software of the mind. McGraw-Hill.

55. Hofstede, G. (1997). Culture and organizations: Software of the mind. New York: McGraw-Hill.

56. Hofstede, G. (2001). Culture's consequences: Comparing values, behaviors, institutions, and organizations across nations (2nd ed.). Thousand Oaks, CA: Sage Publications, Inc.

57. Hofstede, G. \& Bond, M. (1988). The Confucius connection: From cultural roots to economic growth. Organizational Dynamics, 16(4), 4-21.

58. Honeycutt, E., Siguaw, J., \& Hunt, T. (1995). Business ethics and job-related constructs: A cross-cultural comparison of automotive salespeople. Journal of Business Ethics, 14(3), 235-248.

59. Hood, J. N. \& Logsdon, J. M. (2002). Business ethics in the NAFTA countries: A cross-cultural comparison. Journal of Business Research, 55(11), 883-894.

60. Hutchings, K. \& Murray, G. (2003). Family, face, and favors: Do Australians adjust to accepted business conventions in china? Singapore Management Review, 25(2), 25-49.

61. Jaccard, J., \& Wan, C. K. (1986). Cross-cultural methods for the study of behavioral decision making. Journal of Cross-Cultural Psychology, 17(2), 123-149.

62. Jackson, T. (2001). Cultural values and management ethics: A 10-nation study. Human Relations, 54(10), 1267-1303.

63. Jackson, T., David, C., Deshpande, S., Jones, J., Joseph, J., \& Lau, K. (2000). Making ethical judgments: A cross-cultural management study. Asia Pacific Journal of Management, 17, 443-472.

64. Jones, S. \& Hiltebeitel, K. (1995). Organizational influence in a model of the moral decision process of accounts. Journal of Business Ethics, 14(6), 417-431.

65. Jurkiewicz, C. \& Massey, T. (1998). The influence of ethical reasoning on leader effectiveness: An empirical study of nonprofit executives. Nonprofit Management and Leadership, 9(2), 173-186.

66. Karahanna, E., Evaristo, J. R., \& Srite, M. (2005). Levels of culture and individual behavior: An integrative perspective. Journal of Global Information Management, 13(2), 1-20.

67. Keeling, R. M. (Ed.). (1981). Theories of culture. New York: Macmillan.

68. Kidwell, J., Stevens, R., \& Bethke, A. (1987). Differences in ethical perceptions between male and female managers: Myth or reality. Journal of Business Ethics, 6(6), 489-493.

69. Kienzler, D. (2001). Ethics, critical thinking, and professional communication pedagogy. Technical Communication Quarterly, 10(3), 319-339.

70. Klenin, E. R. (1998). The one necessary condition for a successful business ethics course: The teacher must be a philosopher. Business Ethics Quarterly, 8, 561-674.

71. Kohlberg, L. (1984a). The psychology of moral development. San Francisco: Harper \& Row.

72. Kohlberg, L. (Ed.). (1969). Stage and sequence: The cognitive developmental approach to socialization:Chicago: Rand McNally.

73. Kracher, B., Chatterjee, A., \& Lundquist, A. R. (2002). Factors related to the cognitive moral development of business students and business professionals in India and the United States: Nationality, education, sex and gender. Journal of Business Ethics, 34(4), 255-268.

74. Lam, C. F. (2004). Understanding the ethical decisions and behaviours of Hong Kong business managers: An implication for business ethics education. Management Research News, 27(10), 69-77.

75. Larsen, C. A. (2004). The impact of a character development program on moral reasoning, behavior and academic achievement. Dissertation, University of Missouri - Columbia. 
76. Levin, M. (1989, November 25). Ethics courses: Useless. The New York Times, p. A21.

77. Lewin, A. \& Stephens, C. (1994). CEO attitudes as determinants of organization design: An integrated model. Organization Studies, 15(2), 183-212.

78. Lincoln, D., Pressley, M., \& Little, T. (1982). Ethical beliefs and personal values of top level executives. Journal of Business Research, 10(4), 475-487.

79. Longenecker, J., McKinney, J., \& Moore, C. (1988). The ethical issue of international bribery: A study of attitude among U.S. Business professionals. Journal of Business Ethics, 7(5), 341-346.

80. Lu, L. C., Rose, G., \& Blodgett, J. (1999). The effects of cultural dimensions on ethical decision making in marketing: An exploratory study. Journal of Business Ethics, 18(1), 91-105.

81. Mayhew, M. J. (2004). Curricular content and pedagogical practices that influence the development of moral reasoning in undergraduate students. University of Michigan.

82. McCabe, D., Dukerich, J. M., \& Dutton, J. E. (1991). Context, values and moral dilemmas: Comparing the choices of business and law school students. Journal of Business Ethics, 10, 951-960.

83. McCuddy, M. K. \& Peery, B. L. (1996). Selected individual differences and collegians' ethical beliefs. Journal of Business Ethics, 15(3), 261-272.

84. McDonald, G. (2000). Cross-cultural methodological issues in ethical research. Journal of Business Ethics, 27(1/2), 89-104.

85. McNichols, C. \& Zimmerer, T. (1985). Situational ethics: An empirical study of differentiators of student attitudes. Journal of Business Ethics, 4(3), 175-180.

86. Mellahi, K. \& Guermat, C. (2004). Does age matter? An empirical examination of the effect of age on managerial values and practices in India. Journal of World Business, 39(2), 199-215.

87. Michailove, S. (2000). Contrasts in culture: Russian and western perspectives on organizational change. The Academy of Management Executive, 14(4), 99-112.

88. Miesing, P. \& Preble, J. (1985). A comparison of five business philosophies. Journal of Business Ethics, 4(6), 465-476.

89. Moon, Y. S. \& Franke, G. R. (2000). Cultural influence on agency practitioners' ethical perception: A comparison of Korea and the U.S. Journal of Advertising, 29(1), 51-65.

90. Okleshen, M. \& Hoyt, R. (1996). A cross cultural comparison of ethical perspectives and decision approaches of business students: United States of America versus New zealand. Journal of Business Ethics, 15(5), 537-549.

91. Pitta, D., Fung, H., \& Isberg, S. (1999). Ethical issues across cultures: Managing the differing perspective of china and the USA. The Journal of Consumer Marketing, 16(3), 240-253.

92. Posner, B. \& Schmidt, W. (1984). Values and the American managers: An update. California Management Review, 26(3), 202-216.

93. Posner, B. \& Schmidt, W. (1987). Ethics in American companies: A managerial perspective. Journal of Business Ethics, 6(5), 383-391.

94. Purcess, T. V. (1977). Do courses in business ethics pay off? California Management Review, 19(000004), 50-58.

95. Ralston, D. A., Yu, K., Wang, X., Terpstra, R., \& He, W. (1996). The cosmopolitan Chinese manager: Findings of a study on managerial values across the six regions of China. Journal of International Management, 2(2), 79-109.

96. Rest, J. (1979). Development in judging moral issues. Minneapolis, MN: University of Minnesota Press.

97. Rest, J. (1986). Moral development: Advances in research and theory. New York: Praeger.

98. Rest, J. (Ed.). (1994a). Background: Theory and research. L Erlbaum: Hillsdale, NJ.

99. Rest, J., Barnett, R., Bebeau, M., Deemer, D., Getz, L., Moon, Y. S., et al. (1986). Moral development: Advances in research and theory. New York: Praeger Schmitt.

100. Robbins, S. (1994). Management (4th ed.). New Jersey: Prentice Hall.

101. Rogers, A. (1988). Does biology constrain culture? American Anthropologist, 90, 819-831.

102. Rokeach, M. (1973). The nature of human values. New York: Free Press.

103. Rosch, E. (Ed.). (1978). Principles of categorization. Hillsdale, NJ: Lawrence Erlbaum.

104. Ruegger, D. \& King, E. (1992). A study of the effect of age and gender upon student business ethics. Journal of Business Ethics, 11(3), 179-186. 
105. Schneider, S. C. (1989). Strategy formulation: The impact of national culture. Organization Studies, 10, 149168.

106. Schwartz, S. (Ed.). (1992). Universals in the content and structure of values: Theoretical advances and empirical tests in 20 countries. San Diego: Academic Press, Inc.

107. Schwartz, S. \& Blisky, W. (1987). Toward a universal psychological structure of human values. Journal of Personality and Social Psychology, 53, 550-562.

108. Serwinek, P. (1992). Demographic \& related differences in ethical views among small businesses. Journal of Business Ethics, 11(7), 555-566.

109. Shank, M. J. (2005). The impact of moral reasoning on the performance of salespeople. Dissertation, North Carolina State University.

110. Shaver, P. R., Wu, S., \& Schwartz, J. C. (Eds.). (1992). Cross-cultural similarities and differences in emotion and its representation: A prototype approach. Newbury Park, CA: Sage.

111. Singhapakdi, A., Rallapalli, K. C., Rao, C. P., \& Vitell, S. J. (1995). Personal and professional values underlying ethical decisions: A comparison of American and Thai marketers. International Marketing Review, 12(4), 65-76.

112. Singhapakdi, A., Vitell, S., \& Leelakulthanit, O. (1994). A cross-cultural study of moral philosophies, ethical perceptions and judgments: A comparison of American and Thai marketers. International Marketing Review, 11(6), 65-78.

113. Smith, A. \& Rogers, V. (2000). Ethics-related responses to specific situation vignettes: Evidence of genderbased differences and occupational socialization. Journal of Business Ethics, 28(1), 73-86.

114. Smith, A. \& Rogers, V. (2001). Ethics, moral development, and accountants-in-training. Teaching Business Ethics, 5(1), 1-20.

115. Smith, D. E., Skalnik, J. R., \& Shalnic, P. C. (1999). Ethical behavior of marketing managers and mba students: A comparative study. Teaching Business Ethics, 3(4), 321-335.

116. Snodgrass, J. E. (1993). Business ethics: A comparative study of undergraduates. Unpublished doctoral dissertation, University of Idaho.

117. Stevens, G. \& Stevens, F. (1987). Ethical inclinations of tomorrow's managers revisited: How and why students cheat. Journal of Education for Business, 63(1), 24-29.

118. Sweeney, J. (1995). The moral expertise of auditors: An exploratory analysis. Research in Accounting Ethics, $1,213-234$.

119. Thorne, L. \& Saunders, S. B. (2002). The socio-cultural embeddedness of individuals' ethical reasoning in organization. Journal of Business Ethics, 35(1), 1-14.

120. Trevino, L. (1986). Ethical decision making in organizations: A person-situation interactionist model. Academy of Management Review, 11(3), 601-617.

121. Trevino, L. (1992). Moral reasoning and business ethics: Implications for research, education and management. Journal of Business Ethics, 11, 445-459.

122. Tsalikis, J. \& Oritz-Buonafina, M. (1990). Ethical beliefs' differences of males and females. Journal of Business Ethics, 9(6), 509-517.

123. Tsui, J. \& Windsor, C. (2001). Some cross-cultural evidence on ethical reasoning. Journal of Business Ethics, 31(2), 143-150.

124. Vaill, P. (1996). Learning as a way of being: Strategies for survival in a world of permanent white water (1st ed.). San Francisco: Jossey-Bass.

125. Velasquez, M. (1998). Business ethics: Concepts and cases (4th ed.): Upper Saddle River, NJ: Prentice Hall.

126. Venezia, C. C. (2004). The ethical reasoning abilities of accounting students: Comparison from the U.S. And Taiwan. Dissertation, Nova Southeastern University.

127. Vitell, S., Nwachukwu, S., \& Barnes, J. (1993). The effects of culture on ethical decision-making: An application of Hofstede's typology. Journal of Business Ethics, 12, 753-760.

128. Wahn, J. (2003). Sex differences in competitive and compliant unethical work behavior. Journal of Business and Psychology, 18(1), 121-128.

129. Weaver, G. R. (2001). Programs in global businesses: Culture's role in managing ethics. Journal of Business Ethics, 30(1), 3-15.

130. Weber, J. \& Wasieleski, D. (2001). Investigating influences on managers' moral reasoning. Business and Society, 40(1), 79-111. 
131. Weeks, W., Moore, C., McKinney, J., \& Longenecker, J. (1999). The effects of gender and career stage on ethical judgment. Journal of Business Ethics, 20(4), 301-313.

132. Whipple, T. W., \& Swords, D. F. (1992). Business ethics judgments: A cross-cultural comparison. Journal of Business Ethics, 11(9), 671-678.

133. Whitcomb, L. L., Erdener, C. B., \& Li, C. (1998). Business ethical values in china and the U.S. Journal of Business Ethics, 17(8), 839-852.

134. White, R. (1999). Are women more ethical? Recent findings on the effect of gender upon moral development. Journal of Public Administration Research and Theory, 9(3), 459-471.

135. Wimalasiri, J. (2004). Contrasts in moral reasoning capacity: The Fijians and the Singaporeans. Journal of Business Ethics, 49(3), 251-272.

136. Wimalasiri, J., Pavri, F., \& Jalil, A. (1996). An empirical study of moral reasoning among managers in Singapore. Journal of Business Ethics, 15, 1331-1341.

137. Wimbush, J. (1999). The effect of cognitive moral development and supervisory influence on subordinates ethical behavior. Journal of Business Ethics, 18(4), 383-395.

138. Wu, C. F. (2003). A study of the adjustment of ethical recognition and ethical decision-making of managersto-be across the Taiwan strait before and after receiving a business ethics education. Journal of Business Ethics, 45(4), 291-307. 